\title{
Primary Lymphoma of the Central Nervous System: Manitoba Experience and Literature Review
}

\author{
Douglas E. Hobson, Brian A. Anderson, Ian Carr and Michael West
}

\begin{abstract}
We describe eight cases of primary cerebral lymphoma seen in Manitoba from 1980 to 1985.
The clinical presentation is similar to other primary brain tumors. The diagnosis should be considered when single or multiple, often deep lesions, show dense enhancement on computerized tomographic (CT) scan, but are avascular at angiography. These tumors are histologically indistinguishable from non-Hodgkins lymphomas arising outside the CNS.

The prognosis is poor. However, radiotherapy with or without surgery may offer significant palliation. Although there is no consensus on the value of chemotherapy, corticosteroids alone or multiagent chemotherapy have shown promise in a few cases. For these reasons, histologic diagnosis should be sought in all cases and surgery, radiotherapy, and chemotherapy should be considered, as prolonged survival is possible.
\end{abstract}

\begin{abstract}
RÉSUMÉ: Les lymphomes primaires du système nerveux central: Expérience au Manitoba et revue de la littérature Nous décrivons 8 cas de lymphome cérébral primaire vus au Manitoba de 1980 à 1985 . La présentation clinique est semblable à celle des autres tumeurs primaires du cerveau. Le diagnostic doit être considéré lorsque des lésions, souvent profondes, simples ou multiples, montrent une densité augmentée à la tomodensitométrie, tout en étant avasculaires à l'angiographie. Ces tumeurs ne peuvent être distinguées des lymphomes non-Hodgkin originant en dehors du S.N.C.

Le pronostic est mauvais. La radiothérapie, avec ou sans chirurgie, peut offrir un soulagement valable. Même s'il n'existe pas de consensus sur la valeur de la chimiothérapie, quelques cas semblent avoir été aidés par les corticostéroïdes seuls ou la chimiothérapie à agents multiples. A cause de ces résultats, une confirmation histologique s'impose et l'on devrait envisager la chirurgie, la radiothérapie et la chimiothérapie, car certaines longues survies sont possibles.
\end{abstract}

Can. J. Neurol. Sci. 1986; 13:55-61

Primary lymphoma of the CNS constitutes 0.85 to $1.5 \%$ of primary brain tumors. ${ }^{1,2}$ They are diagnosed more often than before, partly due to improved diagnostic procedures. Some suspect an increase in incidence related to the increased use of radiotherapy and immunosuppressants. ${ }^{2}$

Association with renal transplantation, ${ }^{3}$ adult immunodeficiency syndrome,${ }^{4}$ systemic lupus erythematosis, ${ }^{5}$ Sjogren's syndrome, ${ }^{6}$ rheumatoid arthritis, ${ }^{7}$ and immunoglobulin $\mathrm{A}$ deficiency ${ }^{8}$ has been reported. This suggests a relationship to chronic antigenic stimulation. ${ }^{9}$ Louie $^{10}$ suggested the tendency for occurrence in immunosuppressed hosts may indicate a failure of $B$ lymphocyte regulation by $\mathrm{T}$ lymphocytes resulting in neoplastic proliferation of these cells. Most primary CNS lymphomas, however, arise sporadically in patients who have not received immunosuppression and they recapitulate the spectrum of lymphomas arising outside of the CNS. ${ }^{11}$

These tumors were once known by a variety of names notably microglioma and reticulum cell sarcoma. More recently ultrastructural and immunologic studies have shown that they are derived from $B$ lymphocytes, ${ }^{12,13}$ and therefore, should be classified like other malignant lymphomas.

The purpose of this report is to describe eight cases of CNS lymphoma seen in Manitoba and to review the literature. Clinical presentation, radiologic, and histologic features and treatment are discussed.

From the Departments of Medicine (Drs. Hobson and Anderson), Pathology (Dr. Carr), and Surgery (Dr. West), University of Manitoba, Winnipeg Received May 14, 1985. Accepted in revised form September 24, 1985

Reprint requests to: Dr. Brian A. Anderson, Department of Medicine, St.Boniface Hospital, 409 Tache Avenue, Winnipeg, Manitoba, Canada R2H 2A6 


\section{Material and Methods}

Review of hospital records revealed eight cases of primary lymphoma of the CNS presenting to Manitoba's two teaching hospitals (referral population 1,200,000) between January 1980 and December 1984. The charts of these cases were reviewed. Approximately 550 other primary brain tumors presented during this time span.

\section{Results AND Discussion}

Our eight cases are described in Table 1. The staging process included hematologic workup (including bone marrow aspiration and biopsy), SMA-12, chest $x$-ray, and radionucleotide liver and spleen scan. In addition, cases 4,5,7, and 8 had normal abdominal CT scans. Cases 1 and 6 had negative lymphangiograms; cases 3 and 4 had normal intravenous pyelograms. All eight cases were diagnosed pre-mortem by surgical procedures outlined in Table 1. Five cases are still alive. In two of the deaths, autopsy confirmed Stage I disease. No autopsy was performed in the other death. Data from our cases are combined with the series reported in the literature and presented in Table 2. CSF findings are included in Table 4.

\section{Clinical Presentation}

These tumors occur from infancy to old age with a peak occurring in the first decade and from the fourth to the seventh decade. ${ }^{14}$ The average age in 352 cases reviewed was 52 . Male to female ratio was $1.9: 1.0$.

The most common presenting symptoms and signs were nonspecific and nonlocalizing (>80\%). They included headache, nausea and vomiting, possibly implicating raised intracranial pressure (56\%). Confusion, memory loss, and personality change also occurred $(32 \%)$. Focal neurologic symptoms and signs were seen in $42 \%$. Seizures occurred in $9 \%$.

The average duration of symptoms prior to diagnosis was 2.8 months. Our Case 3 is of interest as it suggests the possibility of a primary cerebral lymphoma presenting with seizures 12 years prior to diagnosis, the longest duration reported in the literature.

Table 1: Clinical features, radiologic findings, treatment and outcome in 8 cases of primary CNS lymphoma

\begin{tabular}{|c|c|c|c|c|c|c|c|}
\hline Case & $\begin{array}{l}\text { Age/ } \\
\text { Sex }\end{array}$ & $\begin{array}{l}\text { Clinical Presentation } \\
\text { (Duration of Symptoms } \\
\text { Prior to Diagnosis) }\end{array}$ & $\begin{array}{c}\text { Radiologic } \\
\text { Characteristics }\end{array}$ & $\begin{array}{c}\text { Surgical } \\
\text { Treatment }\end{array}$ & $\begin{array}{c}\text { Histologic } \\
\text { Classification } \\
\text { (Rappaport) }\end{array}$ & $\begin{array}{c}\text { Radiotherapy } \\
\text { and/or } \\
\text { Chemotherapy }\end{array}$ & Follow-Up \\
\hline 1. & $75 \mathrm{~F}$ & $\begin{array}{l}\text { Headache,confusion, } \\
\text { periodic vertigo, ataxia: } \\
\text { on exam, dysarthric speech } \\
\text { L arm \& leg cerebellar } \\
\text { signs ( } 1 \text { month) }\end{array}$ & $\begin{array}{l}\text { CT scan: } L \text { cerebellar } \\
\text { enhancing mass adja- } \\
\text { cent to petrous bone; } \\
\text { hydrocephalus. } \\
\text { Angiography: avascular } \\
\text { mass }\end{array}$ & $\begin{array}{l}\text { Complete } \\
\text { excision }\end{array}$ & Histiocytic & none & $\begin{array}{l}\text { Died of sepsis, } \\
1 \text { mo. Post-mortem } \\
\text { showed no residual } \\
\text { CNSlymphoma and } \\
\text { no lymphoma } \\
\text { outside CNS }\end{array}$ \\
\hline 2. & $70 \mathrm{~F}$ & $\begin{array}{l}\text { Headache,dizziness; on } \\
\text { exam, ?mild expressive } \\
\text { dysphasia ( } 1.5 \text { months) }\end{array}$ & $\begin{array}{l}\text { CT scan: enhancing } \\
\text { mass, } L \text { frontal lobe } \\
\text { adjacent to lateral } \\
\text { ventricle. Angio- } \\
\text { graphy: not done }\end{array}$ & $\begin{array}{l}\text { Partial } \\
\text { excision }\end{array}$ & Histiocytic & $\begin{array}{l}\text { Whole brain } \\
\text { radiation: } \\
3500 \text { rads; } \\
\text { intrathecal } \\
\text { methotrexate }\end{array}$ & $\begin{array}{l}\text { Asymptomatic and } \\
\text { CT scan normal at } \\
18 \text { months. }\end{array}$ \\
\hline 3. & $66 \mathrm{M}$ & $\begin{array}{l}\mathrm{R} \text { focal motor seizures } \\
\mathrm{x} 12 \text { years; Expressive } \\
\text { aphasia, } \mathrm{R} \text { hemiparesis. } \\
\text { drowsy ( } 0.5 \text { months) }\end{array}$ & $\begin{array}{l}\text { CT scan: enhancing } \\
\text { mass, L temporal } \\
\text { lobe. Angiography: } \\
\text { avascular mass. }\end{array}$ & $\begin{array}{l}\text { Partial } \\
\text { excision }\end{array}$ & Histiocytic & $\begin{array}{l}\text { Whole neuro- } \\
\text { axis radia- } \\
\text { tion: } 4500 \\
\text { rads }\end{array}$ & $\begin{array}{l}\text { Good recovery } \\
\text { at } 6 \text { months. }\end{array}$ \\
\hline 4. & $57 \mathrm{M}$ & $\begin{array}{l}\mathrm{R} \text { arm paresthesias. } \mathrm{R} \\
\text { hemiparesis, confusion } \\
(0.5 \text { months })\end{array}$ & $\begin{array}{l}\text { CT scan: enhancing } \\
\text { lesions in } L \text { frontal } \\
\& \text { parietal lobes and } \\
\text { in splenium of corpus } \\
\text { callosum }\end{array}$ & $\begin{array}{l}\text { Needle } \\
\text { Biopsy }\end{array}$ & Histiocytic & $\begin{array}{l}\text { Whole brain } \\
\text { radiation: } \\
5000 \text { rads; } \\
\text { dexamethasone }\end{array}$ & $\begin{array}{l}\text { Died } 38 \text { months } \\
\text { later. Tumor re- } \\
\text { gressed with dexa- } \\
\text { methasone but re- } \\
\text { curred (see dis- } \\
\text { cussion under } \\
\text { treatment) }\end{array}$ \\
\hline 5. & $78 \mathrm{M}$ & $\begin{array}{l}\text { Confusion, } L \text { hemiparesis } \\
\text { (sudden onset) }\end{array}$ & $\begin{array}{c}\text { CT scan: enhancing } \\
\text { mass, L frontal lobe. } \\
\text { Angiography: avascular } \\
\text { mass }\end{array}$ & $\begin{array}{c}\text { Total } \\
\text { excision }\end{array}$ & $\begin{array}{c}\text { Poorly } \\
\text { differentiated } \\
\text { lymphocytic }\end{array}$ & $\begin{array}{l}\text { Whole brain } \\
\text { radiation: } 5000 \text { rads; } \\
\text { dexamethasone }\end{array}$ & $\begin{array}{l}\text { Mild left arm } \\
\text { weakness at } 3 \\
\text { months }\end{array}$ \\
\hline 6. & $70 \mathrm{M}$ & $\begin{array}{l}\text { Confusion, aphasia, } R \\
\text { hemiparesis ( } 2 \text { months) }\end{array}$ & $\begin{array}{l}\text { CT scan: enhancing } \\
\text { frontal mass (butter- } \\
\text { fly distribution). } \\
\text { Angiography: vascular } \\
\text { mass }\end{array}$ & Biospy & $\begin{array}{l}\text { Well different- } \\
\text { iated lymphocytic }\end{array}$ & $\begin{array}{l}\text { Whole brain } \\
\text { radiation } \\
5000 \text { rads; CMOPP } \\
\text { chemotherapy } \\
\text { regime }\end{array}$ & $\begin{array}{l}\text { Well at } 24 \text { months; } \\
\text { mild aphasia. }\end{array}$ \\
\hline 7. & $73 \mathrm{~F}$ & $\begin{array}{l}\text { Lethargy, L hemiparesis, } \\
\text { ataxia (1.5 months) }\end{array}$ & $\begin{array}{l}\text { CT scan: enhancing } \\
\text { lesion in R temporal } \\
\text { lobe adjacent to skull; } \\
\text { thinning of adjacent } \\
\text { skull bone seen. Angio- } \\
\text { graphy: not done. }\end{array}$ & $\begin{array}{c}\text { Complete } \\
\text { excision of } \\
\text { temporal mass }\end{array}$ & Histiocytic & $\begin{array}{l}\text { Whole brain } \\
\text { radiation: } \\
3000 \text { rads; } \\
\text { dexamethasone }\end{array}$ & $\begin{array}{l}\text { Died } 2 \text { months post- } \\
\text { operatively of } \\
\text { sepsis; no residual } \\
\text { tumor was dis- } \\
\text { covered at autopsy. }\end{array}$ \\
\hline 8. & $79 \mathrm{~F}$ & $\begin{array}{l}\text { Recurrent episodes of } \\
\text { confusion with ?aphasia } \\
\text { for } 2 \text { months; admitted } \\
\text { with persistent receptive } \\
\text { aphasia \& early papilledema }\end{array}$ & $\begin{array}{l}\text { CT scan: enhancing } \\
\text { lesion, medial L } \\
\text { temporal lobe. } \\
\text { Angiography: } \\
\text { avascular mass }\end{array}$ & $\begin{array}{l}\text { Partial } \\
\text { excision }\end{array}$ & Histiocytic & $\begin{array}{l}\text { Whole brain } \\
\text { radiation: } \\
5000 \text { rads }\end{array}$ & $\begin{array}{l}\text { Well at } 9 \text { months: } \\
\text { minor residual } \\
\text { aphasia. }\end{array}$ \\
\hline
\end{tabular}


Table 2: Summary of primary cerebral lymphoma series reported in the literature (present study included)

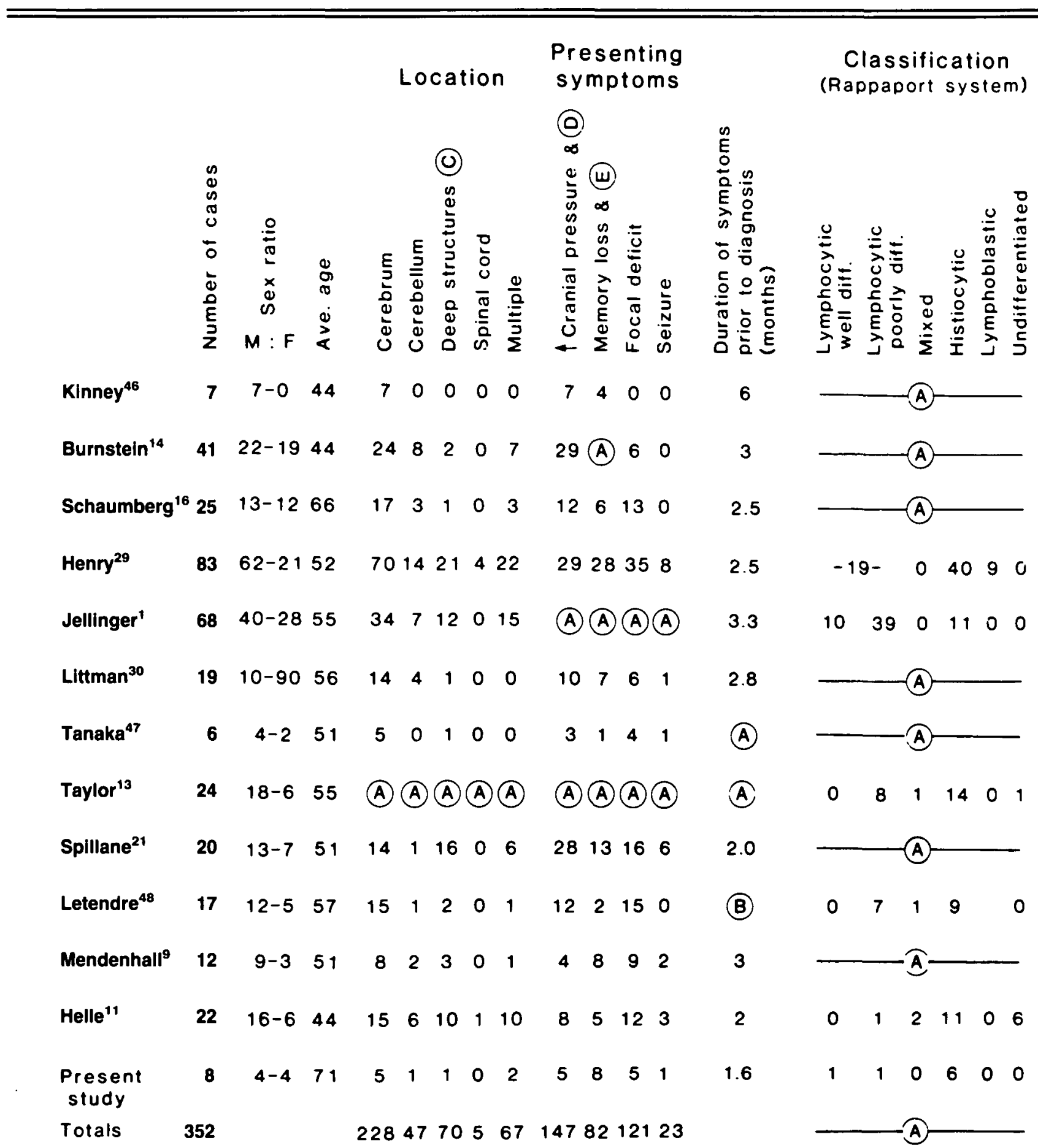

Average

$1.9-1.052$

3 months

Percent

$\begin{array}{lllllllll}55 & 11 & 17 & 1 & 16 & 56 & 32 & 42 & 9\end{array}$

$\begin{array}{llllll}43 & 43 & 2 & 46 & 56 & 4\end{array}$

(A) - Precise information not given in study

(B) -Range 1 to 84 months

(C) -Refers to basal ganglia, thalamus and/or other periventricular locations

(D.) - Includes nonspecific signs, headache, nausea, vomiting

(E) - Personality change, confusion 


\section{Location}

Fifty-five percent of tumors occurred in the cerebral white matter, often within or close to the corpus callosum. Some had a butterfly appearance as seen with some glial tumors. Seventeen percent occurred in deep structures (basal ganglia, thalamus, hypothalamus, periventricular white matter). Eleven percent were in the posterior fossa. One percent involved the spinal cord. They were distinctly uncommon superficially, but have rarely been reported to be localised to the leptomeninges. ${ }^{15}$ Multiple tumors occurred in $16 \%$ of cases.

\section{Radiologic Characteristics}

This topic has been reviewed by many authors. ${ }^{9,16-22}$ Skull films ${ }^{23}$ and radionucleotide brain scans ${ }^{18}$ were abnormal in many cases but did not provide information to help identify the tumor type.

The CT scan characteristics of 29 primary cerebral lymphomas have been described ${ }^{21}$ using $\mathrm{CT}$ scanning without contrast infusion. Twenty-one tumors were dense, five were isodense, two hypodense, and one had variable density in relation to surrounding normal brain tissue. Following contrast infusion, the majority (70\%) showed dense homogeneous enhancement. Ten percent showed no enhancement and $20 \%$ irregular enhancement. Tallroth ${ }^{19}$ also described dense enhancement in the majority of his cases.

Thomas ${ }^{22}$ separated his cases into two groups on the basis of the CT scan characteristics. Deep lesions tended to be well demarcated with little mass effect or surrounding edema, and showed marked homogeneous enhancement. More superficial lesions tended to be poorly demarcated. They had variable density with significant surrounding edema and tended to enhance irregularly. Our results supported this observation.

Ninety-one percent of angiograms performed were abnormal (Table 3). Sixty-three percent showed a mass lesion without increased vascularity. Tumor blush was seen in $28 \%$.

Neither the angiographic nor CT scan appearance is diagnostic of primary cerebral lymphoma. The radiologic picture may suggest glioma, meningioma, or metastatic carcinoma. However, a densely enhancing lesion on CT scan which is avascular on an angiogram should raise suspicion. Multiple lesions with similar characteristics, especially if deeply situated, should also suggest primary cerebral lymphoma ${ }^{19}$.

\section{Cerebrospinal Fluid (CSF) Abnormalities}

Eighty-one percent of reported spinal fluid examinations were abnormal with increased protein in $100 \%$ of those (Table 4). An increased cell count, most frequently mononuclear, was seen in $42 \%$. The accuracy of CSF cytologic diagnosis ranges from $4 \%$ to $43.5 \% .{ }^{24}$ Jellinger ${ }^{24}$ suggests that immunologic studies on CSF might be of value. Analysis of CSF protein may show increased levels of immunoglobulins. More studies are needed to determine if such abnormalities would assist in making tumor-specific diagnosis. Unfortunately, as seen in Table 4, only two of our cases had lumbar punctures. Both were abnormal with positive cytology in one. Immunologic studies were not done.

Table 4: Cerebrospinal fluid findings in $\mathbf{1 2 4}$ cases of primary cerebral lymphoma

\begin{tabular}{|c|c|c|c|c|}
\hline Study & Number & Normal & Avascular Mass & Tumour Blush \\
\hline Helle $^{11}$ & 13 & 0 & 8 & 5 \\
\hline Spillane $^{21}$ & 10 & 0 & 7 & 3 \\
\hline Letendre ${ }^{48}$ & 15 & 1 & 7 & 7 \\
\hline Enzmann $^{18}$ & 7 & 0 & 6 & 1 \\
\hline Present Study & 5 & 1 & 2 & 2 \\
\hline Total & 68 & 5 & 43 & 20 \\
\hline
\end{tabular}

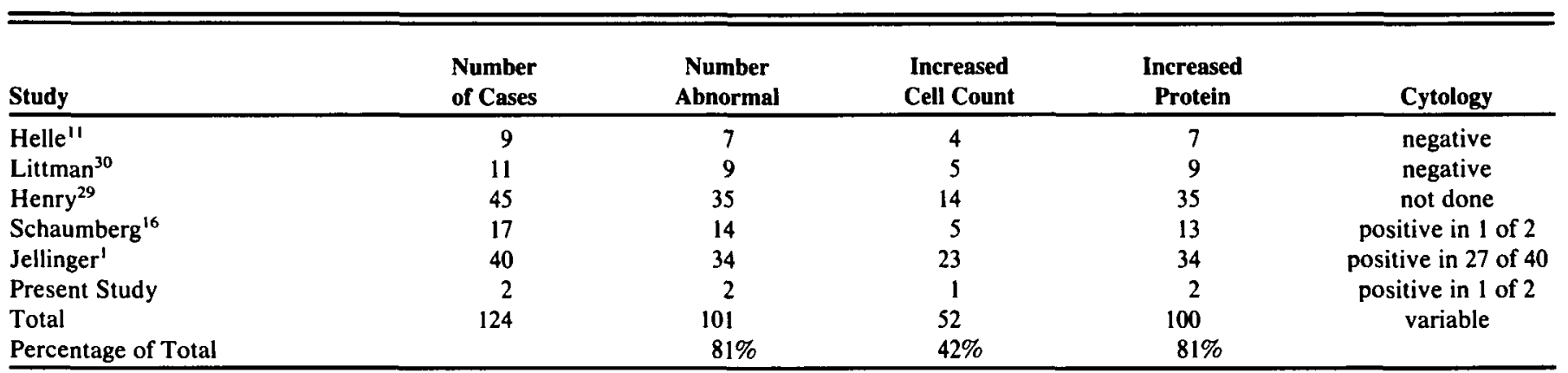




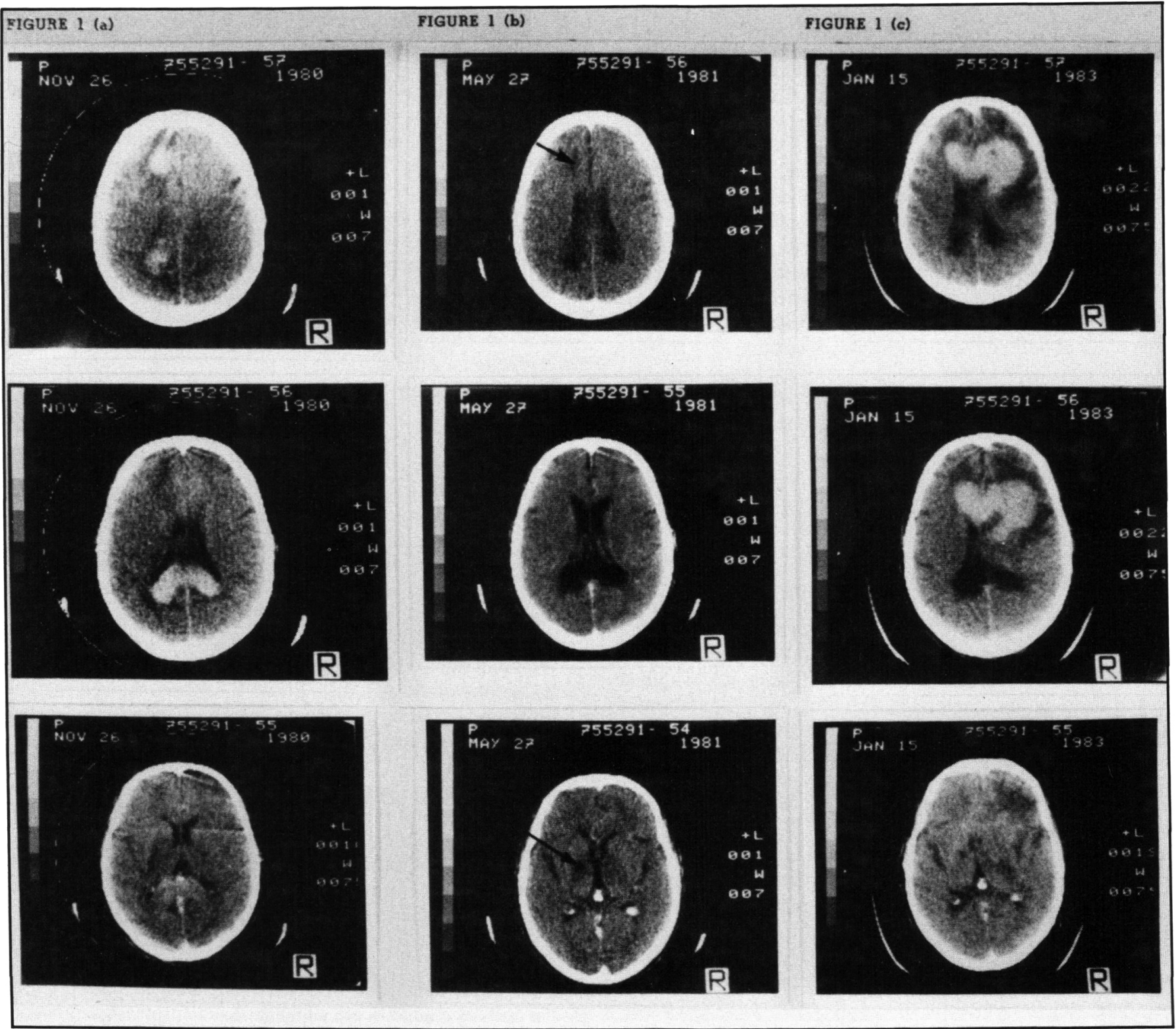

Figure 1 - Serial CT scans in Case 4. - a) Initial CT scan, two weeks postonset of symptoms. Enhancing lesions left frontal and parietal lobes and splenium of corpus callosum. - b) Repeat scan six months later showing marked resolution of the lesions after dexamethasone treatment. Nonenhancing low density areas are seen in the left frontal white matter and left globus pallidus (arrows). Patient was asymptomatic at this time. c) After a further eight months the patient was again symptomatic. Scans show recurrence of enhancing tumor. 


\section{Pathologic Characteristics}

At the time of surgery these tumors are most often found to be soft greyish-pink masses ${ }^{16}$ which can extend to involve meningeal and ependymal surfaces. In two of our cases, the texture was firm, rubbery and lobulated, resembling a meningioma.

Our cases were classified using the Rappaport Classification. ${ }^{25}$ The majority of reported cases are lymphocytic or histiocytic (Table 2). Six of our eight cases were histiocytic, one was a poorly differentiated lymphocytic, and the other a well differentiated lymphocytic lymphoma (Table 2). It is now generally accepted that the great majority of these neoplasms are B-cell derived. Cytologic and immunologic analyses allows identification of B-cell subtypes predominant within a tumor. ${ }^{26}$ There is, to date, no good evidence that this subclassification is of prognostic significance. As well, this information is not currently used in selecting treatment. The use of monoclonal antibodies on paraffin-embedded tissue can help distinguish lymphomas from other small cell tumors. This latter method does not help differentiate from other inflammatory disorders, but is particularly helpful if biopsy material is limited. ${ }^{27}$

\section{Prognosis and Treatment}

The overall prognosis of primary malignant CNS lymphoma is worse than extranodal lymphoma occurring elsewhere. ${ }^{28}$ Helle ${ }^{\prime \prime}$ concluded that a primary CNS lymphoma of diffuse mixed histology or one arising infratentorially is associated with a worse prognosis.

It is generally agreed ${ }^{1,14,29}$ that cranial radiation significantly improves survival. The survival statistics of 68 patients were discussed in the review by Jellinger ${ }^{1}$ and the results were representative of those found elsewhere. The mean survival was two months in those receiving no therapy, one month in those receiving surgery alone, and 16 months in patients treated with surgery and cranial radiation. Mean survival for as long as 45 months has been reported in the latter treatment group. ${ }^{14}$

Surgery is suggested if a well localised lesion can be safely removed. ${ }^{30}$ Overzealous surgery may increase the deficit without improving the long term course. Radiotherapy is an essential complement to any surgical therapy.

The exact dose and field of radiation is debated. Sagerman ${ }^{23}$ reported a high percentage of recurrence with total doses below 3500 rads. Littman ${ }^{30}$ concluded that a total dose between 4500 and 5500 rads was the treatment of choice. More recently Mendenhall ${ }^{9}$ has recommended 4000 to 4500 rads of whole brain radiation with an additional 1500 to 2000 rads to a reduced field around the primary. There is concern however that this "boost" to the tumor may increase the risk of radiation induced encephalopathy. ${ }^{31}$

Littman ${ }^{30}$ suggested spinal axis radiation be given in those cases with positive CSF cytology. Rampen ${ }^{31}$ and Mendenhall ${ }^{9}$ recommended spinal axis radiation in all cases, the recommended dosage being 3000 to 3500 rads.

All patients should have ophthalmologic examination to rule out lymphomatous vitreous involvement ${ }^{9}$ This association is not uncommon and nongranulomatous uveitis has been reported as a presenting feature by several authors. ${ }^{32,33,34}$ If positive, orbital radiation should be given.
No large study of chemotherapy for these tumors has been done. Drugs effective for non-CNS lymphoma (bleomycin, cyclophosphamide, adriamycin, vincristine) have poor bloodbrain-barrier penetration. ${ }^{9}$ Radiosensitizers should be of benefit but tend to have little effect on lymphomas. ${ }^{9}$

Several case reports have suggested some benefit from multiple drug therapy. $9,30,35$ Our case 6 remains alive two years post-treatment with the cyclophosphamide, methotrexate, vincristine, prednisone regime. Amadori ${ }^{36}$ described eight patients with active CNS leukemia and lymphoma whom he treated with a combination of high dose cytosine arabinoside and asparaginase. The former drug has good CNS penetration and the latter is synergistic with it. He suggested the therapy was well tolerated and highly effective in terms of CNS tumor regression. Although none of his cases were primary to the CNS, this therapy might be considered for primary cerebral lymphoma.

Intrathecal methotrexate has been used with some success. ${ }^{37}$ However, there is a risk of necrotizing leukoencephalopathy when this drug is combined with cranial radiation. ${ }^{38}$

Dexamethasone as a chemotherapeutic agent for CNS lymphoma has received little attention. We have noted dramatic improvement in our case 4 (Table 2). This 57 year old male presented with mild right hemiparesis. CT scan showed enhancing lesions in the left frontal and parietal lobes, and in the splenium of the corpus callosum (Figure 1a). Clinical symptoms and signs resolved in two weeks with dexamethasone, 16 milligrams orally per day. Serial CT scans showed marked resolution of the lesions (Figure lb). Dexamethasone was then tapered and stopped over the next six months. No other treatment was given and the patient was asymptomatic for the next year. Symptoms then recurred at which time a repeat CT scan showed recurrent tumor (Figure 1c). Needle biopsy showed histiocytic lymphoma. Five thousand rads of whole brain radiation and dexamethasone provided partial palliation but death occurred eight months later. Cases with a similar marked response to corticosteroids have been described in the literature. ${ }^{40-45}$

\section{Conclusion}

Primary lymphoma of the CNS remains an uncommon disease. The keys to diagnosis are a high index of suspicion and pathologic confirmation. Treatment modalities beyond radiotherapy require controlled studies before a specific regime can be universally recommended.

\section{ACKNOWLEDGEMENTS}

We would like to thank Dr. R. T. Ross, Dr. N. Pillay, and Dr. A. Gomori for their suggestions, and Gail Landry for assistance with manuscript preparation. 


\section{REFERENCES}

1. Jellinger K, Radaskiewcz T, Slowik F. Primary malignant lymphomas of the central nervous system in man. Acta Neuropath (Berlin) 1975; Supp VI, 95-102.

2. Zimmerman $\mathbf{H}$. Malignant lymphomas of the nervous system. Acta Neuropath (Berlin) 1975; Supp VI, 69-74.

3. Schneck S, Penn I. Cerebral neoplasms associated with renal transplantation. Arch Neurol 1970; 22: 226-233.

4. Scully R, Mark E, McNeely B. Case records of the Massachusetts General Hospital, Case 32, 1983. New Eng J Med 1983; 309: 359-369.

5. Lipsmeyer EA. Development of malignant cerebral lymphoma in a patient with systemic lupus erythematosis treated with immunosuppression. Arthritis Rheum 1972; 15: 183-186.

6. Klassen SS, Hoover R, Kimberly R, Budman OR, Decker JL, Chused TM. Increased incidence of malignancy in Sjogren's syndrome (SS)(Abstr) Arthritis Rheum 1977; 20: 123.

7. Good EA, Russo RH, Schnitzer B, Weatherbee L. Intracranial histiocytic lymphoma with rheumatoid arthritis. J Rheumatology 1978; 5: 75-78.

8. Gregory MC, Hughes JT. Intracranial reticulum cell sarcoma associated with immunoglobulin A deficiency. J Neurol Neurosurg Psychiat 1973; 36: 769-776.

9. Mendenhall NP, Thar TL, Agee OF, Harty-Golder B, Ballinger WE, Million RR. Primary lymphoma of the CNS. Computerized tomography scan characteristics and treatment results for 12 cases. Cancer 1983; 52: 1993-2000.

10. Louie S, Schwartz RS. Immunodeficiency and the pathogenesis of lymphoma and leukemia. Semin Hematology 1978; 15: 117-138.

11. Helle T, Britt R, Colby T. Primary lymphoma of the central nervous system - clinicopathologic study of experience of Stanford. J Neurosurgery 1984; 60: 94-103.

12. Horvat B, Pena C, Fisher E. Primary reticulum cell sarcoma (microglioma) of brain - an electron microscopic study. Arch Path 1969; Vol 87: 609-616.

13. Taylor C, Russell R, Lukes R, David R. An immunohistological study of immunoglobulin content of primary central nervous system lymphomas. Cancer 1978; 41: 2197-2205.

14. Burnstein S, Kernohan J, Uihlein A. Neoplasms of the reticuloendothelial system of the brain. Cancer 1963; 16: 290-305.

15. March WL Jr, Stevenson DR, Long HJ. Primary leptomeningeal presentation of T-cell lymphoma. Report of a patient and review of the literature. Cancer 1983; 51: 1125-1131.

16. Schaumberg H, Plank C, Adams R. The reticulum cell sarcomamicroglioma group of brain tumors. Brain 1972; 95: 199-212.

17. Kazner E, Wilske J, Steinhoff $\mathrm{H}$ et al. Computed assisted tomography in primary malignant lymphomas of the brain. J Comp Assist Tomography 1978; 2: 125-134.

18. Enzmann D, Krikorian J, Norman D, Kramer R, Pollock H, Faer $M$. Computed tomography in primary reticulum cell sarcoma of the brain. Radiology 1979; 130: 165-170.

19. Tallroth K, Kateue K, Holst L, Andersson U. Angiography and computed tomography in the diagnosis of primary lymphoma of the brain. Clinical Radiology 1981; 32: 383-388.

20. Thomson J, Brownell B. Computer tomographic appearances in microgliomatosis. Clinical Radiology 1981; 32: 367-374.

21. Spillane J, Kendal B, Moseley I. Cerebral lymphoma: clinical radiological correlation. J Neurol Neurosurg Psychiat 1982; 45: 199-208.

22. Thomas M, MacPherson P. Computed tomography of intracranial lymphoma. Clinical Radiology 1982; 33: 331-336.

23. Sagerman RH, Cassaday JR, Chang $\mathrm{CH}$. Radiation therapy for intracranial lymphoma. Radiology 1967; 88: 552-554.

24. Jellinger K. Primary lymphomas of the CNS. Arch Neurology 1982; 39: 458.

25. Rappaport H. Tumors of the hematopoietic system. In: "Atlas of tumor pathology", 1966; Washington DC, Armed Forces Institute of Pathology, Section III, Fascicle 8, p. 99-101.
26. Robbins SL, Cotran RS, Kumar V. Pathologic bases of disease, 1984; Chapter 15, Diseases of white cells, lymph nodes and spleen, 3rd edition, W.B.Saunders, p. 653-704.

27. Warnke RA, Gatter KC, Brunangelo F, Hildreth P, Woolston RE, Pulford K, Cordell JL, Cohen B, De Wolf-Peeters C, Mason DY. Diagnosis of human lymphoma with monoclonal antileukocyte antibodies. New Eng J Med 1983; 309: 1275-1281.

28. Mukherji B, Yagoda A, Lee BH, Kradkoff IH. A clinical study of the natural history of lymphosarcoma and reticulum cell sarcoma. Eur J Cancer 1974; 10: 497-505.

29. Henry J, Heffner R, Dillard S, Earle K. Davis R. Primary malignant lymphoma of the central nervous system. Cancer 1974; 34: 1293-1302.

30. Littman P, Wang CC. Reticulum cell sarcoma of the brain: A review of the literature and a study of 19 cases. Cancer 1975; 35: 1412-1420.

31. Rampen FH, Van Andel JG, Sizoo W, Unnik J. Radiation therapy in primary non Hodgkin's lymphoma of the CNS. Eur J Cancer 1980; 16: 177-184.

32. Givner I. Malignant lymphoma with ocular involvement. A clinicopathologic report. Am J Ophthalmol 1955; 39: 29-32.

33. Parver LM, Font RL. Malignant lymphoma of the retina and brain. Initial diagnosis by cytologic examination of vitreous aspirate. Arch Ophthalmol 1979; 97: 1505-1507.

34. Rosenbaum TJ, MacCarty, CS, Buettner H. Uveitis and cerebral reticulum-cell sarcoma (large-cell lymphoma). Case Report. J Neurosurg 1979; 50: 660-664.

35. Stewart DJ, Russell N, Atack EA, Quarrinton A, Stolback L. Cyclophosphamide, doxorubicin, vincristine and dexamethasone in primary lymphoma of the brain: A Case Report. Cancer Treatment Reports 1983; Vol 67 No 3, 287-291.

36. Amadori S, Papa G, Avvisati G, Petti M et al. Sequential combination of systemic high dose ara-C and asparaginase for the treatment of central nervous system leukemia and lymphoma. J Clin Oncology 1984; 2: 98-101.

37. Herbst KD, Corder MP, Justice GR. Successful therapy with methotrexate of a multicentric mixed lymphoma of the central nervous system. Cancer 1976; 38: 1476-1478.

38. Duttera MH, Bleyer WA, Pomeroy TC et al. Irradiation, methotrexate toxicity and the treatment of meningeal leukemia. Lancet 1973; 2: 703-707.

39. Wallack EM, Reavis WM Jr, Hall CD. Primary brainstem reticulum cell sarcoma causing dementia. Dis Nerv Syst 1977; 38: 744-747.

40. Ruff RL, Petito CK, Rawlinson DG. Primary cerebral lymphoma mimicking multiple sclerosis. Arch Neurol 1979; 36: 598.

41. Williams RS, Crowell RM, Fisher CM et al. Clinical and radiological remission in reticulum cell sarcoma of the brain. Arch Neurol 1979; 36: 206-210

42. Singh A, Strobos RJ, Singh BM et al. Steroid induced remissions in CNS lymphoma. Neurology (NY) 1982; 32: 1267-1271

43. Scully RE, Mark EJ, McNeely BU. Case records of the Massachusetts General Hospital. Weekly clinicopathological exercises. Case 31-1982. New Eng J Med 1982; 307: 359-368.

44. Vaquero J, Martinez R, Rossi E, Lopez R. Primary cerebral lymphoma: the "ghost tumor". Case report. J Neurosurg 1984; 60: 174-176.

45. Coca A, Goday A, Font J, Ingelmo M, Balcells A. Letter to the Editor re: Primary cerebral lymphoma: the "ghost tumor". J Neurosurg 1984; 61: 202.

46. Kinney T, Adams R. Reticulum cell sarcoma of brain. Arch Neurol Psych 1943; 50: 552-564.

47. Tanaka T, Nishimoto A, Doi A, Nagao S, Hujita M, Sesaki T, Yumoto T. Primary intracranial malignant lymphomas with particular reference to their pathogenesis. Acta Path Jap 1977; 27(6): 927-940.

48. Letendre L, Banks PM, Freese DF, Miller RH, Scanlon PW, Kiely JM. Primary lymphoma of the central nervous system. Cancer 1982; 49: 939-943. 